\author{
Aleksander STARAKIEWICZ ${ }^{1}$ \\ Lech LICHOLAI ${ }^{2}$ \\ Przemysław MIĄSIK ${ }^{3}$ \\ Joanna KRASON ${ }^{4}$
}

\title{
ZUŻYCIE NOŚNIKÓW ENERGII W BUDYNKU JEDNORODZINNYM NA CELE OGRZEWANIA CIEPŁEJ WODY UŻYTKOWEJ I POTRZEB BYTOWYCH
}

\begin{abstract}
$\mathrm{W}$ artykule, przedstawiono faktyczne zużycie energii w istniejącym budynku jednorodzinnym w latach 2009 - 2015. Podstawą analizy są dane rzeczywistego zużycia nośników energii elektrycznej, węgla kamiennego, drewna przez instalację c.w.u. i c.o., ciepłej wody użytkowej, energii z kolektorów słonecznych oraz czasu pracy instalacji słonecznej. Przedstawiono również miesięczne zużycie rodzajów energii w systemie ogrzewania i ciepłej wody użytkowej w 2010 r. Omówiono wyposażenie budynku w instalacje wewnętrzne i sprzęt AGD oraz ich wpływ na ilość zużywanych nośników energii.
\end{abstract}

Słowa kluczowe: zużycie opału, zużycie energii elektrycznej, energia z kolektorów słonecznych, zużycie ciepłej i zimnej wody

\section{Wprowadzenie}

Każdy budynek mieszkalny wykonany jest z określonych materiałów i technologii, wyposażony w instalacje i urządzenia niezbędne do zaspokojenia potrzeb bytowych jego mieszkańców. Ilość niezbędnej energii wymaganej do utrzymania komfortu cieplnego budynku oraz zaspokojenia potrzeb bytowych jego mieszkańców zależy od wielu czynników. Są one zależne od izolacyjności obudowy budynku, warunków klimatycznych, rodzaju i jakości instalacji, wyposażenia w sprzęt AGD i jego jakości, przyzwyczajeń i ekologiczną świadomością użytkowników związaną z koniecznością oszczędzania energii. Budynek w czasie swojego użytkowania spełnia określone funkcje, co wymaga dostarczenia odpo-

\footnotetext{
${ }^{1}$ Aleksander Starakiewicz, Politechnika Rzeszowska, Zakład Budownictwa Ogólnego, ul. Poznańska 2, 35-959 Rzeszów; tel. 178651428; olekstar@prz.edu.pl

2 Lech Lichołai, Politechnika Rzeszowska; tel. 178651327; Lech.Licholai@prz.edu.pl

3 Przemysław Miąsik, Politechnika Rzeszowska; tel. 178651702; pmiasik@prz.edu.pl

${ }^{4}$ Joanna Krasoń, Politechnika Rzeszowska; tel. 178651728; jkras@prz.edu.pl
} 
wiedniej ilości energii. Może pochodzić z różnych źródeł: konwencjonalnych (węgiel, drewno, gaz, olej opałowy, energia elektryczna) i odnawialnych (słońce, wiatr, woda, grunt, geotermia). W budynkach mieszkalnych energia wykorzystywana jest na potrzeby ogrzewania i wentylacji, przygotowania ciepłej wody użytkowej, chłodzenia, oświetlenia oraz pracy sprzętu AGD. Zależnie od wieku budynku i jego wyposażenia, może on wykorzystywać energię konwencjonalną, konwencjonalną i odnawialną lub tylko odnawialną. Wraz z rozwojem ,technologii instalacyjnych" coraz częściej sięgamy po OZE (odnawialne źródła energii) oraz energooszczędne rozwiązania możliwe do zastosowania w budynku. Efektem takich działań jest zmniejszenie całkowitego zużycia energii w budynku, a przede wszystkim tej pochodzącej z konwencjonalnych źródeł.

Szacowanie zużywanej energii może odbywać się zarówno na podstawie obliczeń teoretycznych, ale i pomiarów faktycznego zużycia energii. Stąd też zasadne jest przedstawienie spojrzenia na potrzeby energetyczne w analizowanym budynku mieszkalnym, zarejestrowane na przestrzeni ostatnich kilku lat. Wybrane fragmenty tego zagadnienia były już poruszane na poprzednich Konferencjach Solina 2008 i 2010 [1, 2]. Zagadnienie ograniczania zużycia energii w budynkach jest ciągle aktualne, realizowane jest poprzez akty prawne dotyczące izolacyjności cieplnej budynków (warunki techniczne - WT 2015, [3]) ale również wynika z ochrony środowiska naturalnego człowieka (zmniejszenie emisji gazów cieplarnianych, wykorzystywanie odnawialnych źródeł energii - dyrektywy UE, [4, 5].

\section{Obliczanie zużycia energii elektrycznej w budynku}

Do obliczania zużycia energii elektrycznej w budynku niezbędnej do utrzymania w ruchu instalacyjnych urządzeń technologicznych oraz na potrzeby bytowe (wewnętrzne zyski ciepła) posłużono się zmodyfikowanymi algorytmami przedstawionymi poniżej. $\mathrm{ru}[6]$ :

Miesięczne zużycie energii do przygotowania posiłków oblicza się ze wzo-

$$
\mathrm{Q}_{\mathrm{ic}}(\mathrm{m})=0,001 * \Phi_{\mathrm{c}} * \mathrm{t}_{\mathrm{M}}[\mathrm{kWh}]
$$

gdzie: $\Phi_{\mathrm{c}}$ - uśredniony strumień cieplny od gotowania posiłków odniesiony do jednego mieszkania $w[\mathrm{~W}]$;

$\mathrm{t}_{\mathrm{M}}$ - liczba godzin w miesiącu;

Miesięczne zużycie energii do zasilania elektrycznych urządzeń oświetleniowych oblicza się ze wzoru [6]:

$$
\mathrm{Q}_{\text {ios }}(\mathrm{m})=0,001 * \Phi_{\mathrm{os}} * \mathrm{t}_{\mathrm{M}}[\mathrm{kWh}]
$$

gdzie: $\Phi_{\text {os }}$ - uśredniony strumień cieplny od elektrycznych urządzeń oświetleniowych odniesiony do jednego mieszkania $\mathrm{w}[\mathrm{W}]$; 
Zużycie energii do zasilania urządzeń elektrycznych oblicza się ze wzoru [6]:

$$
\mathrm{Q}_{\mathrm{iel}}(\mathrm{m})=0,001 * \Phi_{\mathrm{el}} * \mathrm{t}_{\mathrm{M}}[\mathrm{kWh}]
$$

gdzie: $\Phi_{\mathrm{el}}-$ uśredniony strumień cieplny od urządzeń elektrycznych odniesiony do jednego mieszkania w [W];

Wewnętrzne zyski ciepła w budynku oblicza się ze wzoru [7]:

$$
\mathrm{Q}_{\text {int }}=0,001 * \mathrm{q}_{\text {int }} * \mathrm{~A}_{\mathrm{f}} * \mathrm{t}_{\mathrm{M}}[\mathrm{kWh}]
$$

gdzie: $\mathrm{q}_{\text {int }}$ - obciążenie cieplne pomieszczeń wewnętrznymi zyskami ciepła, [W/m²];

$A_{f}$ - powierzchnia pomieszczeń o regulowanej temperaturze powietrza

(powierzchnia ogrzewana lub chłodzona), $\left[\mathrm{m}^{2}\right]$;

W tabeli 1 przedstawiono obliczenia szczegółowe, rocznego zużycia energii elektrycznej dla różnych odbiorników. Wykonano je w oparciu o nieobowiązującą już normę [6], ponieważ tylko w niej są podane zredukowane strumienie ciepła dla poszczególnych odbiorników. Obliczenia przedstawiono dla 2006 ro$\mathrm{ku}$ (maksymalne zużycie energii w historii budynku) oraz dla $2015 \mathrm{r}$ (minimalne zużycie). Uzyskane wyniki wewnętrznych zysków ciepła wg [6] porównano z tymi, obliczonymi wg obowiązującej metodologii [7].

Tabela 1. Roczne obliczeniowe zużycia energii na potrzeby bytowe oraz wewnętrzne zyski ciepła

\begin{tabular}{|c|c|c|c|c|c|c|}
\hline \multirow[b]{2}{*}{ Lp. } & \multirow[b]{2}{*}{$\begin{array}{l}\text { Odbiornik energii } \\
\text { elektrycznej lub } \\
\text { źródło energii }\end{array}$} & \multicolumn{2}{|c|}{2006} & \multicolumn{2}{|c|}{2015} & \multirow[b]{2}{*}{$\begin{array}{l}\text { Wewnętrz. } \\
\text { zyski ciepła } \\
\text { wg [7] }\end{array}$} \\
\hline & & $\begin{array}{c}\text { Uśredniony } \\
\text { strumień } \\
\text { ciepła [6] }\end{array}$ & $\begin{array}{l}\text { Roczne } \\
\text { zużycie } \\
\text { energii }\end{array}$ & \begin{tabular}{|c|} 
Uśredniony \\
strumień \\
ciepła $[6]$
\end{tabular} & $\begin{array}{l}\text { Roczne } \\
\text { zużycie } \\
\text { energii }\end{array}$ & \\
\hline & - & [W] & {$[\mathrm{kWh}]$} & {$[\mathrm{W}]$} & {$[\mathrm{kWh}]$} & kWh] \\
\hline 1. & Kuchnia elektr. & $2 * 110$ & 1927,2 & 100 & 876,0 & \multirow{14}{*}{ 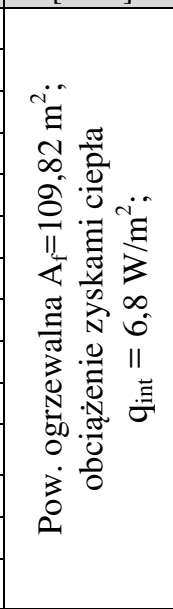 } \\
\hline 2. & Oświetlenie & 60 & 525,6 & 30 & 262,8 & \\
\hline 3. & Lodówka & 40 & 350,4 & 10 & 87,6 & \\
\hline 4. & Zamrażarka & 102 & 893,5 & 22,5 & 197,1 & \\
\hline 5. & Pralka & 25 & 219,0 & 19,5 & 170,8 & \\
\hline 6. & Telewizor & $2 * 35$ & 613,2 & 20 & 175,2 & \\
\hline 7. & Czajnik elektr. & 20 & 175,2 & 20 & 175,2 & \\
\hline 8. & Komputer & 25 & 219,0 & 20 & 175,2 & \\
\hline 9. & Zmywarka $^{2)}$ & - & & 20 & 44,2 & \\
\hline 10. & Pozostałe & 27,5 & 240,9 & 16,2 & 141,9 & \\
\hline 11. & suma roczna & - & 5164,0 & - & 2306,0 & \\
\hline 12. & Mieszkańcy & $6 * 65$ & 3416,4 & $3 * 65$ & 1708,4 & \\
\hline 13. & Od c.w.u. & $6 * 15+25$ & 1007,4 & $3 * 15+25$ & 613,2 & \\
\hline 14. & suma $(12+13)$ & - & 4423,8 & - & 2314,6 & \\
\hline 15 . & Zyski wew. (11+14) & - & 9587,8 & - & 4627,4 & 6541,8 \\
\hline
\end{tabular}

Table 1. Annual calculation of energy consumption for household needs and internal heat gains 


\section{Opis konstrukcji budynku oraz systemów ogrzewania i przygotowania ciepłej wody użytkowej}

Analizowany obiekt to budynek jednorodzinny, wolnostojący, całkowicie podpiwniczony, dwukondygnacyjny (parter i piętro), z poddaszem (strychem) nieogrzewanym, przykryty dachem czterospadowym. Budynek jest zamieszkiwany przez czteroosobową rodzinę dwupokoleniową, wcześniej przez sześcioosobową trzypokoleniową. Zmienna liczba mieszkańców budynku została opisana pod tabelą nr 4. W nieogrzewanym podpiwniczeniu znajduje się garaż, piwnica, kotłownia, spiżarnia, klatka schodowa i schowek (skład opału). Na parterze znajdują się pomieszczenia do wspólnego użytkowania przez rodzinę: ganek, hol, klatka schodowa, kuchnia, dwa pokoje i łazienka ogólna. Na piętrze rozmieszczenie pomieszczeń jest identyczne: trzy pokoje, łazienka, hol i klatka schodowa. Ściany zewnętrzne wykonane są w konstrukcji dwuwarstwowej, gdzie warstwę konstrukcyjną stanowi mur z cegły ceramicznej pełnej o grubości $1 \mathrm{i} 1 / 2$ cegły $(40 \mathrm{~cm})$, a warstwę izolacji termicznej styropian o grubości $10 \mathrm{~cm}$ w technologii lekkiej mokrej z akrylowym tynkiem cienkowarstwowym. Przeprowadzono również docieplenie stropu nad piwnicą (styropian grubości $5 \mathrm{~cm}$ przyklejono do sufitu w piwnicy) oraz stropu nad piętrem (styropian grubości 10-15 cm rozłożono na stropie poddasza). W latach 1998-2002 wymienione zostały wszystkie okna i drzwi balkonowe. Wykonano je z profili drewnianych warstwowo klejonych $\left(\mathrm{U}_{\mathrm{f}}=1,45 \mathrm{~W} / \mathrm{m}^{2} \mathrm{~K}\right) \mathrm{z}$ oszkleniem niskoemisyjnym jednokomorowym $\left(\mathrm{U}_{\mathrm{g}}=1,1 \mathrm{~W} / \mathrm{m}^{2} \mathrm{~K}\right)$. Na klatce schodowej wymiany okien dokonano w 2010 roku, profile sześciokomorowe $\mathrm{z}$ PVC $\left(\mathrm{U}_{\mathrm{f}}=1,2 \mathrm{~W} / \mathrm{m}^{2} \mathrm{~K}\right)$ z oszkleniem niskoemisyjnym dwukomorowym $\left(\mathrm{U}_{\mathrm{g}}=0,6 \mathrm{~W} / \mathrm{m}^{2} \mathrm{~K}\right)$. System grzewczy w budynku stanowi instalacja centralnego ogrzewania, w której źródłem ciepła jest stalowy kocioł centralnego ogrzewania z tzw. górnym spalaniem paliwa stałego o sprawności nominalnej $82 \%$, przeznaczony do spalania koksu, węgla kamiennego, miału lub drewna. Kocioł c.o. jest konwencjonalnym źródłem ciepła dla instalacji centralnego ogrzewania i instalacji przygotowania ciepłej wody użytkowej. Elementami grzejnymi w całym budynku stanowią członowe grzejniki żeliwne wyposażone w zawory termostatyczne, a w łazienkach grzejniki drabinkowe. Instalacja grzewcza wyposażona jest w pompę obiegową zsynchronizowaną z pracą kotła c.o. Przewody rozprowadzające czynnik grzewczy są zaizolowane (wełna szklana, owijka, gips) i poprowadzone pod sufitem w pomieszczeniach piwnicy. Instalacja ciepłej wody użytkowej zasilana jest z dwóch źródeł ciepła, kolektorów słonecznych oraz kotła c.o. W rozważanym budynku jednorodzinnym ciepła woda użytkowa (c.w.u.) przygotowywana jest centralnie i gromadzona w zasobniku biwalentnym o pojemności 300 litrów oraz 70 litrowej termie elektrycznej. Zasobnik posiada dodatkową grzałką oraz dwie wężownice, gdzie dolna zasilana jest z instalacji słonecznej a górna (w razie potrzeby) $\mathrm{z}$ instalacji c.o. Terma wykorzystywana jest, jako zasobnik rezerwowy. Instalacja c.w.u. wyposażona jest w system cyrkulacyjny, który służy również do przerzucania c.w.u. z zasobnika do termy. Instalacja jest tak zaprojektowana, aby możliwe było pobieranie c.w.u. z zasobnika lub termy. Instalacja słoneczna składa się z dwóch kolektorów o łącznej, czynnej powierzchni absorbera 4,70 m². Kolektory skierowane są na południe i ustawione pod kątem $55^{\circ}$ do poziomu [2]. 


\section{Wyniki badań zużycia energii w budynku na podstawie pomiarów rzeczywistych}

W niniejszym rozdziale przedstawiono wyniki zużycia energii w budynku jednorodzinnym opracowane na podstawie pomiarów przeprowadzonych od 1-go stycznia 2009 r. do końca grudnia 2015 r. Zużycie energii elektrycznej, opału, energii pozyskanej z kolektorów słonecznych oraz łącznej ilości energii wykorzystanej przez analizowany budynek zestawiono w tabelach poniżej. Opał stosowany w budynku to węgiel kamienny oraz drewno. Dane wyjściowe to ilość zużytego opału w kilogramach. Zarejestrowane ilości paliwa przeliczono na wartość energii w kWh, przyjmując kaloryczność w zależności od roku zakupu: dla węgla kamiennego 25,0 - 30,0 MJ $/ \mathrm{kg}=6,94-8,33 \mathrm{kWh} / \mathrm{kg}$, dla drewna $15,25 \mathrm{MJ} / \mathrm{kg}=4,24 \mathrm{kWh} / \mathrm{kg}$. Średnia temperatura c.w.u. w zaworze czerpalnym wynosiła $45^{\circ} \mathrm{C}$ a wody zimnej $10^{\circ} \mathrm{C}$, stąd przy obliczeniu energii $\Delta \mathrm{t}=35^{\circ} \mathrm{C}$.

Tabela 2. Miesięczne zużycie energii w systemie ogrzewania i ciepłej wody użytkowej w $2010 \mathrm{r}$.

Table 2. Monthly energy consumption of the heating system and hot water in 2010

\begin{tabular}{|c|c|c|c|c|c|c|c|}
\hline \multirow{3}{*}{ 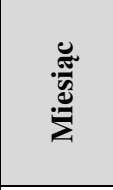 } & \multicolumn{2}{|c|}{ Energia elektryczna } & \multicolumn{2}{|c|}{ Energia konwencjonalna } & \multirow[b]{2}{*}{$\begin{array}{c}\text { Energia } \\
\text { z kolektorów } \\
\text { słonecznych }\end{array}$} & \multirow{2}{*}{\multicolumn{2}{|c|}{$\begin{array}{l}\text { Lączna ilość zuży- } \\
\text { wanej energii } \\
\text { w budynku }\end{array}$}} \\
\hline & \multirow{2}{*}{$\begin{array}{c}\begin{array}{c}\text { Instalacja } \\
\text { c.o. } \\
\text { (pompa) }\end{array} \\
{[\mathrm{kWh}]} \\
\end{array}$} & \multirow{2}{*}{$\begin{array}{r}\begin{array}{r}\text { Instalac. } \\
\text { kol. słon. } \\
\text { (pompa) }\end{array} \\
{[\mathrm{kWh}]} \\
\end{array}$} & \multirow{2}{*}{\begin{tabular}{|c|c|}
$\begin{array}{c}\text { Węgiel } \\
\text { kamienny }\end{array}$ \\
{$[\mathrm{kWh}]$} \\
\end{tabular}} & \multirow{2}{*}{\begin{tabular}{c|} 
Drewno \\
{$[\mathrm{kWh}]$} \\
\end{tabular}} & & & \\
\hline & & & & & [kWh] & {$[\mathrm{kWh}]$} & {$[\%]$} \\
\hline $\mathrm{I}$ & 12,1 & 0,45 & 7154,2 & 571,9 & 52,5 & 7791,2 & 21,3 \\
\hline II & 8,7 & 1,86 & 4852,1 & 610,0 & 241,0 & 5713,7 & 15,6 \\
\hline III & 11,2 & 3,39 & 3364,6 & 724,4 & 559,0 & 4662,6 & 12,7 \\
\hline IV & 4,1 & 3,93 & 1636,3 & 533,8 & 641,0 & 2819,1 & 7,7 \\
\hline $\mathrm{V}$ & 3,3 & 3,93 & 0,0 & 190,6 & 547,0 & 744,8 & 2,0 \\
\hline VI & 1,0 & 4,62 & 0,0 & 122,8 & 64 & 769,4 & 2,1 \\
\hline VII & 0,9 & 1,68 & 0,0 & 114,4 & 235,0 & 352,0 & 1,0 \\
\hline VIII & 1,2 & 1,98 & 0,0 & 46,6 & 390,0 & 439,8 & 1,2 \\
\hline IX & 2,9 & 1,44 & 786,3 & 118,6 & 235,0 & 1144,2 & 3,1 \\
\hline $\mathrm{X}$ & 1,1 & 0,63 & 2847,5 & 144,0 & 81,0 & 3074,2 & 8,4 \\
\hline $\mathrm{XI}$ & 7,7 & 0,42 & 2578,3 & 508,3 & 59,0 & 3153,7 & 8,6 \\
\hline XII & 10,7 & 0,18 & 5440,0 & 499,9 & 25,0 & 5975,8 & 16,3 \\
\hline średnia & 5,4 & 2,04 & 2388,5 & 348,6 & 308,9 & 3053,4 & 8,3 \\
\hline suma & 64,9 & 24,51 & 28659,2 & 4185,3 & 3706,5 & 36640,4 & 100,0 \\
\hline Udział & $0,18 \%$ & $0,07 \%$ & $78,22 \%$ & $11,42 \%$ & $10,12 \%$ & $100 \%$ & \\
\hline
\end{tabular}

Całkowite zużycie energii $\mathrm{z}$ węgla kamiennego i drewna na potrzeby ogrzewania, energii do przygotowania ciepłej wody użytkowej pochodzącej z kolektorów słonecznych oraz energii elektrycznej zużywanej przez oświetlenie, system ogrzewczy i przygotowania ciepłej wody użytkowej oraz urządzenia elektryczne (zamrażarka, lodówka, kuchnia, czajnik, komputer, itd.) w kolejnych miesiącach roku oraz kolejnych latach, przedstawiono w tabelach 2 i 3. 
Tabela 3. Zużycie energii w systemie ogrzewania i ciepłej wody użytkowej w latach 2009-2015

Table 3. Consumption of energy in the heating system and hot water in 2009-2015

\begin{tabular}{|c|c|c|c|c|c|c|c|}
\hline \multirow{3}{*}{ Rok } & \multicolumn{2}{|c|}{ Energia elektryczna } & \multicolumn{3}{|c|}{ Energia konwencjonalna } & \multirow[b]{2}{*}{$\begin{array}{c}\text { Energia } \\
\text { z kolektorów } \\
\text { słonecznych }\end{array}$} & \multirow[b]{2}{*}{$\begin{array}{l}\text { Lączna } \\
\text { ilość } \\
\text { energii }\end{array}$} \\
\hline & $\begin{array}{c}\text { Instalacja } \\
\text { c.o. }\end{array}$ & $\begin{array}{c}\text { Instalacja } \\
\text { kolekt. sło- } \\
\text { necz. }\end{array}$ & $\begin{array}{c}\text { Węgiel } \\
\text { kamienny }\end{array}$ & Drewno & $\begin{array}{c}\text { Suma } \\
(4+5)\end{array}$ & & \\
\hline & [kWh] & [kWh] & [kWh] & [kWh] & [kWh] & [kWh] & [kWh] \\
\hline 2009 & 107,9 & 24,09 & 25868,1 & 4892,7 & 30760,8 & $\left.4610,0^{*}\right)$ & 35502,7 \\
\hline 2010 & 64,9 & 24,51 & 28659,2 & 4185,3 & 32844,5 & $\left.3706,5^{*}\right)$ & 36640,4 \\
\hline 2011 & 95,9 & 9,06 & 24220,0 & 7396,3 & 31616,3 & 1756,0 & 33477,3 \\
\hline 2012 & 128,0 & 10,98 & 23183,9 & 8556,9 & 31740,8 & 1536,0 & 33415,8 \\
\hline 2013 & 108,0 & 8,48 & 24775,0 & 3689,7 & 28464,7 & 1136,0 & 29717,2 \\
\hline 2014 & 97,2 & 7,92 & 20846,7 & 3435,5 & 24282,2 & 1033,0 & 25420,3 \\
\hline 2015 & 128,7 & 8,10 & 21991,7 & 3071,2 & 25062,9 & 1035,0 & 26234,7 \\
\hline Średnia & 104,4 & 13,30 & 24220,6 & 5032,5 & 29253,1 & 2116,1 & 31486,9 \\
\hline Śr. udział & $0,33 \%$ & $0,04 \%$ & $76,92 \%$ & $15,98 \%$ & $92,91 \%$ & $6,72 \%$ & $100 \%$ \\
\hline
\end{tabular}

Tabela 4. Zużycie rodzajów energii i wody w budynku w latach 2009-2015

Table 4. Consumption types of energy and water in the building in 2009-2015

\begin{tabular}{|c|c|c|c|c|c|c|c|c|c|}
\hline \multirow[b]{2}{*}{ Rok } & \multirow{2}{*}{$\begin{array}{c}\text { Energia } \\
\text { elektr. } \\
\text { całego } \\
\text { budynku }\end{array}$} & \multicolumn{3}{|c|}{ Węgiel kamienny } & \multirow{2}{*}{$\begin{array}{l}\text { Zużycie } \\
\text { drewna }\end{array}$} & \multirow{2}{*}{\begin{tabular}{|c|}
$\begin{array}{c}\text { Energia } \\
\text { słoneczna }\end{array}$ \\
$\begin{array}{c}\text { Kolekt. } \\
\text { ciepłej } \\
\text { wody }\end{array}$ \\
\end{tabular}} & \multicolumn{2}{|c|}{ Ciepła woda } & \multirow{2}{*}{$\begin{array}{c}\text { Zużycie } \\
\text { zimnej } \\
\text { wody }\end{array}$} \\
\hline & & Zużycie & $\begin{array}{l}\text { Wartość } \\
\text { opałowa }\end{array}$ & Energia & & & $\begin{array}{l}\text { Zuży- } \\
\text { cie 4) }\end{array}$ & $\begin{array}{c}\text { Energia } \\
\Delta \mathrm{t}=\mathbf{3 5}^{\circ} \mathrm{C}\end{array}$ & \\
\hline- & [kWh] & 8] & | & {$[1,1,1]$} & [n] & [kWh] & {$[111]$} & {$[\mathrm{R} / \mathrm{NI}]$} & {$[\mathrm{Ii1}]$} \\
\hline 2009 & & & & & & & & & \\
\hline 2010 & 305 & fO & & & & & & & 132,3 \\
\hline 2011 & 3007 & 3114 & 28,0 & 24220,0 & 1746,0 & 1756,0 & 86,3 & 25155 & $148 ?$ \\
\hline 2012 & $2528^{5)}$ & 2878 & 29,0 & 23183,9 & 2020,0 & 1536,0 & 82,9 & 3377,0 & 158,2 \\
\hline 2013 & $2454^{3)}$ & 2973 & 30,0 & 24775,0 & 871,0 & 1136,0 & 81,6 & 3324,1 & 141,4 \\
\hline 2014 & 2527 & 2544 & 29,5 & 20846,7 & 811,0 & 1033,0 & 77,8 & 3169,3 & 154,0 \\
\hline 2015 & $2306^{1,2)}$ & 2730 & 29,0 & 21991,7 & 725,0 & 1035,0 & 61,4 & 2501,2 & $118,6^{2)}$ \\
\hline Średnia & 2764 & 3144 & 28,0 & 24220,6 & 1188,0 & 2116,1 & 82,9 & 3375,9 & 145,7 \\
\hline
\end{tabular}

*) Eksploatacja instalacji słonecznej z poszukiwaniem optymalnych parametrów pracy, (długiego czasu pracy instalacji w ciągu dnia - kilka godzin pracy na tzw. jałowym biegu);

1) - od 1.06.2015 r. w całym budynku występuje oświetlenie LED;

2) - od 3.01.2015 r. nowa energooszczędna pralka a od 1.10.2015 r. zainstalowano zmywarkę do naczyń.

3) - od 15.09.2013 r. zainstalowano kuchnię indukcyjną w miejsce gazowo-elektrycznej

4) - budynek zamieszkuje: 2009 r. - 5 osób; 2010-2014 r. - 4 osoby; 2015 r.- 3 osoby;

5) - od 1.01.2012 r. w całym budynku występuje oświetlenie energooszczędne. 


\section{Analiza wyników}

Roczne zużycie energii końcowej w analizowanym budynku, na potrzeby ogrzewania i wentylacji oraz przygotowania ciepłej wody użytkowej w okresie siedmiu lat (2009 - 2015) kształtuje się w przedziale 25420,3 - 36640,4 kWh, przy średniej wartości z tego okresu $31486,9 \mathrm{kWh}$. Analizując wyniki zużycia tej energii, przedstawione $\mathrm{w}$ tabeli 4, należy stwierdzić, że ilość zużywanej energii w budynku w ciągu danego roku zależała od lokalnych warunków klimatycznych (temperatura zewnętrzna, wiatr, promieniowanie słoneczne). Dwie kolejne mroźne zimy 2009 i 2010 roku spowodowały największe zużycie energii końcowej w budynku, natomiast dwie ostatnie łagodne zimy 2014 i 2015 roku dały najmniejsze zużycie energii. Odchylenie rocznego zużycia energii od wartości średniej wyniosło $+16,4 \%$ i $-19,3 \%$ a różnica bezwzględna to $35,7 \%$.

Analizując miesięczne zużycia energii końcowej na potrzeby ogrzewania i wentylacji oraz przygotowania ciepłej wody użytkowej w 2010 roku należy stwierdzić, że styczeń jest miesiącem o największym jej zużyciu (21,3\%). Kolejne miesiące to grudzień $(16,3 \%)$, luty $(15,6 \%)$, marzec $(12,7 \%)$ itd. - tabela 1. Dwa zimowe miesiące styczeń i grudzień dają łączne zużycie energii na poziomie $(37,8 \%)$, a cztery najzimniejsze miesiące, grudzień - marzec, kształtują to zużycie na poziomie $(65,9 \%)$. Rozkład procentowego miesięcznego zużycia energii w pozostałych latach ma bardzo zbliżoną charakterystykę, różnice występują natomiast w ilości zużywanej energii.

Największe zużycie energii elektrycznej w historii budynku odnotowano w 2004 roku (9043 kWh) [1], gdy ciepła woda użytkowa podgrzewana była w dwóch termach elektrycznych, gdzie na ten cel zużywano 4633 kWh $(51,2 \%)$, a na pozostałe potrzeby bytowe $4410 \mathrm{kWh}(48,8 \%)$.

Największe zużycie energii elektrycznej na potrzeby bytowe $(5163 \mathrm{kWh})$ zanotowano w roku 2006, a od którego jej zużycie systematycznie spada. W 2009 roku zużycie tej energii obniżyło się do 3469 kWh (spadek o 32,8\%) a w 2015 roku do $2306 \mathrm{kWh}$ (spadek o 55,3\%). Na obniżanie zużycia energii miały wpływ sukcesywnie realizowane następujące przedsięwzięcia: wymiana 18-letniej zamrażarki „Mors” na energooszczędną klasy A+, wprowadzenie oświetlenia energooszczędnego, wymiana kuchni elektryczno-gazowej na indukcyjną, wymiana oświetlenia energooszczędnego na LED-owe, wymiana lodówki i pralki na energooszczędne klasy $\mathrm{A}++$, wymiana telewizora na LCD, zakup zmywarki do naczyń.

Wyraźnie widzimy jak ważną rolę w zużyciu energii elektrycznej na potrzeby bytowe odgrywa energooszczędny sprzętu AGD i jego klasa, co szczegółowo przedstawiono $\mathrm{w}$ tabeli 1 . Sumując zużycie energii na potrzeby bytowe, zyski ciepła od mieszkańców i zyski od ciepłej wody użytkowej, otrzymujemy wewnętrzne zyski ciepła w budynku. Obliczane wg metodologii wewnętrzne zyski ciepła znacznie różnią się od tych z 2006 i 2015 roku. Starszej generacji sprzęt AGD generuje większe zyski ciepła w budynku o 46,6\%, względem tych 
obliczanych wg metodologii [7], natomiast energooszczędny sprzęt AGD znacznie je ogranicza (mniejsze o 29,3\%).

\title{
Literatura
}

[1] Starakiewicz A.: Badania zużycia energii na potrzeby bytowe w budynku mieszkalnym, ZN PRz nr 252, Budownictwo i Inżynieria Środow. Nr 47, 2008, s. 477-481.

[2] Starakiewicz A.: Eksploatacja instalacji c.w.u. z kolektorami słonecznymi w budynku mieszkalnym, ZN PRz nr 271, Budow. i Inżyn. Środ. nr 57, 4/2010, s. 509-513.

[3] Obwieszczenie Ministra Infrastruktury i Rozwoju z dnia 17 lipca 2015 r. w sprawie ogłoszenia jednolitego tekstu rozporządzenia Ministra Infrastruktury ws. warunków technicznych, jakim powinny odpowiadać budynki i ich usytuowanie, Dz. U. z 18 września 2015 r., poz. 1422.

[4] Dyrektywa Parlamentu Europejskiego i Rady 2010/31/UE z dnia 19 maja 2010 r. ws. charakterystyki energetycznej budynków, Dz. Urz. UE L 153 z 18.06.2010, s. 13.

[5] Dyrektywa Parlamentu Europejskiego i Rady 2009/28/UE z dnia 23 kwietnia 2009 r. ws. promowania stosowania energii ze źródeł odnawialnych zmieniająca i w następstwie uchylająca dyrektywy 2001/77/WE oraz 2003/30/WE, Dz. Urz. UE L 140 z 5.06.2009, s. 16.

[6] PN-B-02025:2001 „Obliczanie sezonowego zapotrzebowana na ciepło do ogrzewania budynków mieszkalnych i zamieszkania zbiorowego".

[7] Rozporządzenie Ministra Infrastruktury i Rozwoju z dnia 27 lutego 2015 r. w sprawie metodologii wyznaczania charakterystyki energetycznej budynku lub części budynku oraz świadectw charakterystyki energet., Dz. U. z 18 marca 2015 r., poz. 376.

\section{CONSUMPTION ENERGY CARRIERS IN THE RESIDENTIAL BUILDING FOR HEATING, HOT WATER AND LIVING NEEDS}

\begin{abstract}
S u m m a r y
In an article for an existing single-family building shows the actual energy consumption in the years 2009-2015. The analysis is based on actual consumption data carriers of electricity, coal, wood, hot and cold water, the energy from the solar collectors and the time of the installation. It also presents monthly energy consumption of the heating system and hot water in 2010. Discussed furnishing internal installations and appliances and their impact on the amount of consumed energy.
\end{abstract}

Keywords: fuel consumption, electricity consumption, energy from solar collectors, the consumption of hot and cold water

DOI:10.7862/rb.2016.227

Przestano do redakcji: $14.09 .2016 r$.

Przyjęto do druku: 30.11.2016r. 